Int. J. Dev. Biol. 61: 601-610 (2017)

doi: $10.1387 / \mathrm{ijdb} .170236 \mathrm{ik}$

\title{
Dorsal-ventral patterning in amphioxus: current understanding, unresolved issues, and future directions
}

\author{
IRYNA KOZMIKOVA*,1 and JR-KAI YU*,2 \\ ${ }^{1}$ Institute of Molecular Genetics of the Czech Academy of Sciences, Prague, Czech Republic, and \\ ${ }^{2}$ Institute of Cellular and Organismic Biology, Academia Sinica, Nankang, Taipei, Taiwan
}

\begin{abstract}
How the embryonic body axis is generated is a fundamental question in developmental biology. The molecular mechanisms involved in this process have been the subject of intensive studies using traditional model organisms during the last few decades, and the results have provided crucial information for understanding the formation of animal body plans. In particular, studies exploring the molecular nature of Spemann's organizer have revealed the intricate interactions underlying several signaling pathways (namely the Wnt/ $\beta$-catenin, Nodal and Bmp pathways) that pattern the dorsoventral (DV) axis in vertebrate embryos. Furthermore, recent comparative studies have shown that many of these signaling interactions are also employed in other non-vertebrate model organisms for their early embryonic axis patterning. These results suggest that there is deep homology in DV patterning mechanisms among bilaterian animals and that these mechanisms may be traced back to the common ancestor of cnidarians and bilaterians. However, the mechanism by which the DV axis became inverted in the chordate lineage relative to the DV axis in other bilaterian animals remains unclear. Cephalochordata (i.e., amphioxus) represent a basal chordate group which occupies a key phylogenetic position for explorations of the origin of the chordate body plan. In this review, we summarize what is currently known regarding the developmental mechanisms that establish the DV axis in amphioxus embryos. By comparing this to what is known in vertebrates, we can start to hypothesize about the ancestral DV patterning mechanisms in chordates and discuss their possible evolutionary origins.
\end{abstract}

KEY WORDS: dorsal-ventral patterning, organizer, signaling pathway, chordate, evolution

\section{Introduction}

Bilaterian body plans are generally characterized by three major axes: the anteroposterior (AP) axis, the dorsoventral (DV) axis, and the left-right (LR) axis. Since the beginning of experimental embryology, studies have been focused on deciphering the cellular mechanisms that instruct the generation of proper body axes in a diverse array of organisms. This line of efforts led to the discovery of the dorsal organizer (the Spemann organizer) in amphibian embryos by Spemann and Mangold (Spemann and Mangold, 1924). They demonstrated that the dorsal mesoderm (dorsal blastopore lip) of an early gastrula stage amphibian embryo has the ability to instruct the formation of a proper vertebrate body plan. If grafted to the ventral side of a host embryo, this piece of dorsal mesoderm can induce the formation of a twinned embryo with a secondary body axis. Subsequent studies in other vertebrate systems identified corresponding tissues with similar organizing activities (reviewed in (Anderson and Stern, 2016), suggesting that the use of a dorsal organizer to pattern the vertebrate body plan is conserved.

Since the discovery of the vertebrate dorsal organizer, the mechanisms involved in its formation and patterning functions have been intensively investigated. This has been especially true in recent decades, during which researchers have identified the molecular mechanisms associated with the vertebrate dorsal organizer mainly by using the Xenopus and zebrafish embryos as

Abbreviations used in this paper: BMP, bone morphogenetic protein; DV, dorsoventral.

\footnotetext{
*Address correspondence to: Iryna Kozmikova. Institute of Molecular Genetics of the Czech Academy of Sciences, Videnska 1083, Prague, 14220, Czech Republic. E-mail: kozmikova@img.cas.cz (iD) http://orcid.org/0000-0002-7861-9802

or Jr-Kai SkyYu. Institute of Cellular and Organismic Biology Academia Sinica, 128 Academia Road, Sec. 2 Nankang, Taipei 11529, Taiwan.

E-mail: jkyu@gate.sinica.edu.tw - (D) http://orcid.org/0000-0001-8591-0529
}

Submitted: 15 September, 2017; Accepted: 22 September, 2017.

ISSN: Online 1696-3547, Print 0214-6282

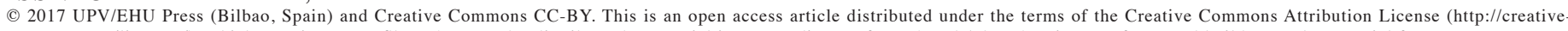

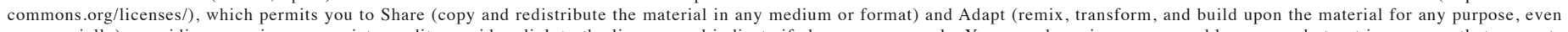

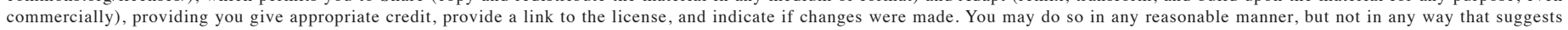
the licensor endorses you or your use. Printed in Spain 
models (reviewed in (De Robertis, 2009; De Robertis and Kuroda, 2004; Niehrs, 2004; Thisse and Thisse, 2015; Tuazon and Mullins, 2015). We now know that although the dorsal organizer is definitively set at the start of gastrulation in vertebrate embryos, the molecular processes that are required for its formation act prior to that. The Wnt/ $\beta$-catenin, Nodal, and Bmp signaling pathways (Fig. 1) play essential roles in properly establishing the dorsal organizer and patterning the overall DV axis in vertebrates. For example, after fertilization, in Xenopus embryos, cortical rotation moves maternally deposited dorsal determinants (including the components of the $\mathrm{Wnt} / \beta$-catenin pathway) from the vegetal side towards the dorsal side. Subsequently, the Wnt/ $\beta$-catenin pathway is activated synergistically with the vegetal factors VegT and Vg1 to activate Nodal-related genes and create a gradient of Nodal-related proteins that is low in the ventral endoderm and high in the dorsal endoderm of the blastula. This protein gradient then induces the overlaying mesoderm to specify further signaling centers in the following areas: the mesoderm receiving little or no Nodal signal becomes the ventral mesoderm that produces Bmp signaling ligands (including Bmp4 and Bmp7) and their modulators (including Tsg, CV-2, and Xolloid), while the mesoderm receiving the highest concentration of Nodal forms the dorsal organizer that secretes a suite of diffusible factors, including inhibitors of the Bmp, Wnt, and Nodal signaling pathways (reviewed in (De Robertis, 2009;
De Robertis and Kuroda, 2004). Ultimately, through the molecular interactions that occur among the proteins produced by the ventral signaling center and dorsal organizer, a Bmp signaling gradient is set up along the DV axis (high ventrally and low dorsally) across all three germ layers, and this gradient governs the development of distinct cell types at specific positions along the DV axis (Bier and De Robertis, 2015).

Notably, in vertebrate embryos, the inhibition of Bmp signaling on the dorsal side induces the formation of the central nervous system (CNS) from dorsal ectoderm, the notochord from axial dorsal mesoderm, and somites from paraxial dorsal mesoderm. These structures represent the definitive characters of the chordate body plan. This suggests that the proper establishment of the dorsal organizer and its axial patterning activities might be associated with the origin of the chordate body plan. To trace the evolutionary origin of the dorsal organizer, we must turn our attention to the two invertebrate chordate groups, the urochordates and cephalochordates. Urochordates are now considered the sister group of vertebrates (Bourlat et al., 2006; Delsuc et al., 2006); however, they undergo a very rapid and highly determined early developmental process to form their tadpole-like larvae (Lemaire, 2011), and their highly derived developmental mechanisms therefore provide little information regarding the evolution of the dorsal organizer. On the other hand, cephalochordates (i.e., amphioxus) represent

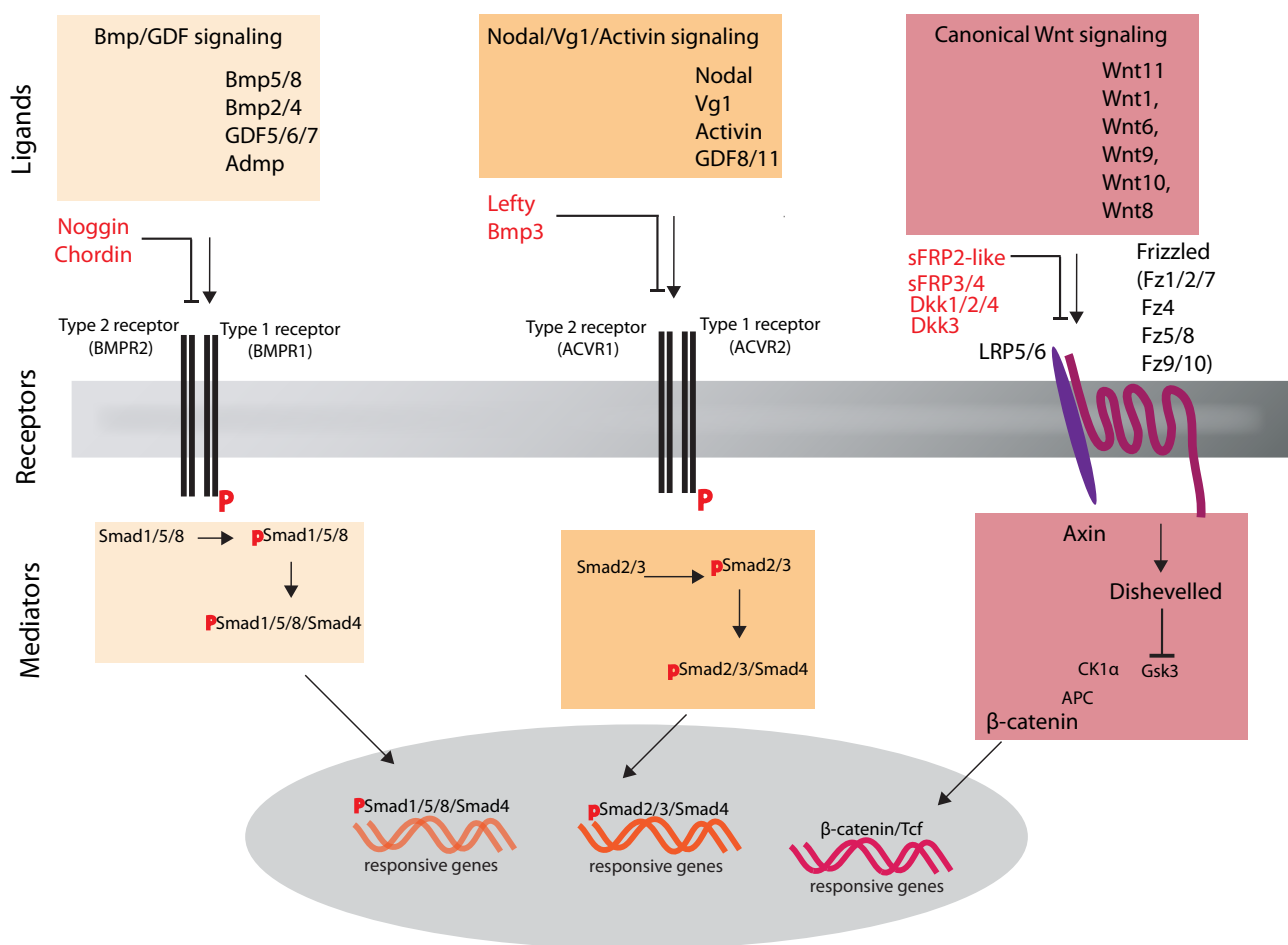

Fig. 1. Simplified scheme of the Bmp, Nodal and Wnt/ $\beta$-catening signaling pathway functioning. Indicated members of signaling pathways are present in the amphioxus. The signaling proteins involved in the Bmp/ GDF and Nodal/Activin pathways belong to the TGF $\beta$ superfamily ligands, which bind to the type 2 receptors to form a complex that results in the phosphorylation of type 1 receptors. The type 1 receptor then phosphorylates intracellular receptor-regulated Smad proteins (R-Smads), which then bind to the Smad4 protein to generate R-Smad/ Smad4 complexes (Kitisin et al., 2007). These complexes are capable of entering the nucleus, where they bind to DNA and function as transcription factors to regulate gene expression. The ligands of the Bmp/ GDF pathway, Bmps and some growth and differentiation factors (GDFs) (e.g., GDF5, GDF6, and GDF7) interact with specific type-2 BMP receptors (BMPR2). BMPR2 bind to type-1 BMP receptors (i.e., BMPR1A or BMPR1B). This leads to the recruitment and phosphorylation of intracellular Smad1, Smad5 or Smad8 proteins, which form receptor complexes with the Smad4 protein (Kitisin et al., 2007; Liu and Niswander 2005). Nodal and GDF1 signaling proteins interact with activin $A$ receptor type $2 B$ (ACVR2B); Activins and GDF11 interact with activin $A$ receptor, type $2 A$ (ACVR2A). Both the ACVR2B and ACVR2A bind to activin A receptor, type 1B (ACVR1B), which triggers the phosphorylation of Smad2 or Smad3. Phosphorylated Smad2 and Smad3 then form complexes with Smad4 to function as transcription factors (Kitisin et al., 2007; Papanayotou and Collignon, 2014). In canonical Wnt signaling, Wnt ligands interact with Frizzled (Fz) family receptors and their co-receptors, lipoprotein receptor-related proteins (Lrp5/6) (reviewed in (MacDonald and He, 2012). Then, the signal is transduced to the intracellular phosphoprotein dishevelled (Dvl), which is located in the cytoplasm. Activated Dvl inhibits glycogen synthase kinase 3 (Gsk3) activity in the destruction complex, which degrades $\beta$-catenin in the absence of Wnt signals. The destruction complex also includes the following proteins: axin, adenomatosis polyposis coli (APC), protein phosphatase 2A (PP2A), and casein kinase $1 \alpha(C K 1 \alpha)$ (reviewed in (Stamos and Weis, 2013). Stabilized $\beta$-catenin is accumulated in the cytoplasm and eventually translocated into the nucleus, where it acts as a transcriptional coactivator with transcription factors that belong to the TCF/LEF family (Hikasa and Sokol, 2013). 
an early branch of the chordate group, and more importantly, both classical grafting experiments and recent molecular analyses have demonstrated that the dorsal blastopore lip of the amphioxus gastrula has the ability to induce a partial (Tung et al., 1962) or complete (Le Petillon et al., 2017) secondary axis and expresses an array of regulatory genes similar to that expressed by the vertebrate dorsal organizer (Tung et al., 1962; Yu et al., 2007). Furthermore, recent studies have shown that the Nodal and Bmp signaling pathways appear to play conserved roles in amphioxus DV patterning (Kozmikova etal., 2013; Le Petillon et al., 2017; Onai et al., 2010), although the role of $\mathrm{Wnt} / \beta$-catenin in amphioxus early axial patterning is less clear. In this review, we aim to summarize the current state of research on the formation of the amphioxus organizer and DV axis patterning from the start of development through the early gastrula stage. We place emphasis on the roles of signaling pathways, especially the Nodal, Bmp, and Wnt signaling pathways. We intend to integrate the available data related to the activities of these signaling pathways and discuss their roles in the formation of the dorsal organizer during the early development of amphioxus embryos.

\section{Maternal signals in early amphioxus embryos}

The animal and vegetal hemispheres are established within the unfertilized amphioxus egg during oogenesis (Frick and Ruppert, 1997). Cortical granules occupy the cortex of the unfertilized egg, and the subcortical cytoplasm in the vegetal third of the egg contains sheets of dense granules that are interleaved with the cisternae of the endoplasmic reticulum (Holland and Holland, 1992; Holland and Holland, 1991). These vegetal structures are associated with numerous ribosomes and mRNAs of germ cell marker genes, such as Vasa, Nanos, Piwil1, Tudor, Pl10, and bruno2 (Dailey et al., 2016; Wu et al., 2011; Yue et al., 2015; Zhang et al., 2013). On the other hand, the transcripts of the following genes are localized in the animal hemisphere in the amphioxus egg: Nodal, SoxB1b, and Tcf (Cattell et al., 2012; Lin et al., 2006; Onai et al., 2010). Among these, Tcf is a downstream transcription factor that mediates canonical Wnt/ $\beta$-catenin signaling (Fig. 1 ).

Transcript distribution patterns of several components of the canonical Wnt $/ \beta$-catenin signaling pathway have been recently analyzed using in situ hybridization in fertilized amphioxus eggs (Qian etal., 2013; Wang et al., 2016b). Dvl, which acts directly downstream of the Wnt signaling receptor Frizzled (Fig. 1), is asymmetrically localized toward the animal pole in the one-cell stage embryos (Fig. 2) (Wang et al., 2016b). Lrp5/6, Axin, Gsk3 $\beta, A P C$, Gro, Ckl $\alpha$, $C k / 3 \beta$, and $C k / \delta$ are present at the one-cell stage, but their transcripts are ubiquitously distributed (Wang

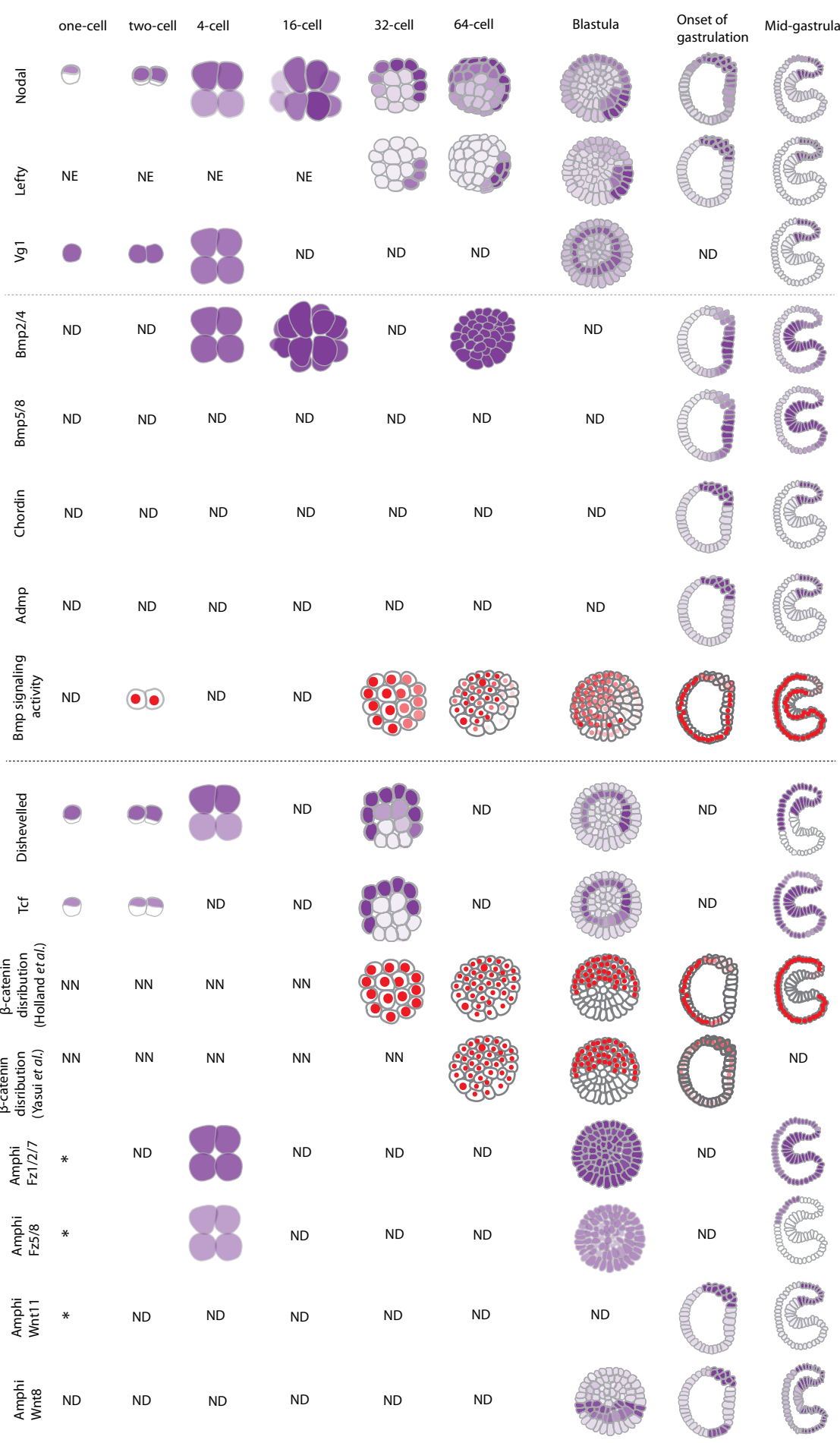

Fig. 2. Distribution of selected components of signaling pathways during amphioxus early development. $N D$, not determined; $N N$, no nuclei; $N E$, not expressed; and (*), expression was detected using RT-PCR. The animal pole is at the top of the embryos in cleavage and blastula stages, and dorsal side is at the top during the onset of gastrulation and midgastrula stages. Violet color marks the mRNA expression of the genes. Red color marks nuclear protein localization of phosphorylated pSmad 1/5/8 in the case of Bmp signaling and against $\beta$-catenin in the case of Wnt/ $\beta$-catenin signaling. Based on the data from: (Holland et al., 2005; Kozmikova et al., 2013; Lin et al., 2006; Morov et al., 2016; Onai et al., 2010; Qian et al., 2013; Schubert et al., 2000a; Schubert et al., 2000b; Wang et al., 2016a; Yasui et al., 2002; Yu et al., 2007), and this report (Fig. 5). 
et al., 2016b), indicating that these components are already present in the unfertilized egg. Additionally, four Frizzled receptors are maternally expressed in amphioxus (Qian et al., 2013). For Wnt ligands, Wnt1, Wnt6, Wnt9, Wnt10, and Wnt11 were shown to be maternally expressed at low levels when they were analyzed using RT-qPCR. Wnt4 is also likely to be maternally expressed because its transcripts can be detected in 4-cell stage embryos (Qian et al., 2013). On the other hand, the transcripts of Wnt3, Wnt5, Wnt7, and Wnt 8 are not detectable prior to the blastula stage, suggesting that they are only expressed zygotically after the blastula stage (Qian et al., 2013).

Despite the presence of numerous constituents of the canonical $W n t / \beta$-catenin signaling pathway, the main downstream effector, $\beta$-catenin, was not detected in the nuclei of one- or two-cell stages of the amphioxus embryos. In unfertilized egg, the distribution of maternal $\beta$-catenin protein was found to be uniform within the cytoplasm by immunostaining. However, after fertilization, the $\beta$-catenin protein seems to be preferentially localized toward the animal pole (Holland et al., 2005; Yasui et al., 2002), which roughly corresponds to the future anterior side. Then, at the 16-cell (Holland et al., 2005), using B. floridae) or 64-cell stage (Yasui et al., 2002), using B. belcheri/japonicum), nuclear $\beta$-catenin protein signals can be detected in all blastomeres. These observations suggest that in amphioxus, the $\beta$-catenin protein distribution pattern in early cleavage-stage embryos may be different from the general situation found in other deuterostome animals, where it is usually localized at the vegetal pole (Range, 2014). We will further discuss the issue of the localization of amphioxus $\beta$-catenin protein in later sections.

The sperm entry site is important for determining the embryonic axes in some vertebrates (Moon and Kimelman, 1998) and ascidians (Sardet et al., 2007). The existing literature presents two opinions that diverge regarding the importance of the entrance of sperm for DV polarity in the amphioxus. One opinion is based on EM observations and proposes that sperm preferentially enter at the animal hemisphere (Holland and Holland, 1992; Holland and Onai, 2012) (Fig. 3A) and after fertilization migrate to the vegetal pole. Here, the chromatin de-condenses as the oocyte undergoes its second maturation division, and subsequently, the second po- these observations, the authors suggested that the sperm entry points and the location of the male pronuclei are inconsistent with the stereotypical movement of the male pronucleus, and hence, the sperm entry site is not important for establishing the DV polarity in amphioxus embryos (Morov et al., 2016). These authors also showed that in amphioxus, the active form of the Arp2/3 complex, which functions during the activation of the cytoskeletal reorganization of the cell (Mullins et al., 1998; Pollard, 2007), changes its distribution within the egg during the first several minutes of development after fertilization (Morov et al., 2016). This may indicate the existence of previously unrecognized cytoplasmic/ cortical movement in fertilized amphioxus eggs, similar to what has been observed in ascidian (Sardet et al., 2007) or Xenopus eggs (Rowning et al., 1997). Furthermore, this report showed that the active form of the Arp2/3 complex moves to the animal pole in the cortical region of amphioxus zygotes, and that this movement influences the distribution of maternal Nodal mRNA toward the animal pole (Morov et al., 2016) (Fig. 4). Although there are no data showing the localization of phosphorylated Smad2/3 protein, which would indicate the region of activity of Nodal/Vg1 signaling, functional experiments that used pharmacological inhibitors of Smad2/3-mediated signaling showed that Nodal is an essential maternal factor mediating the specification of the dorsal region in the early amphioxus embryo (Morov et al., 2016; Onai et al., 2010).

\section{Distribution of transcripts and the activity of signaling pathways from cleavage stage to early gastrula stage}

In amphioxus, the first cleavage produces two blastomeres of equal size, and the second polar body is located on one of these blastomeres (Hirakow and Kajita, 1990). The second cleavage results in four loosely connected cells of roughly equal volume, with one of these blastomeres containing the germ granule (Wu et al., 2011). The third cleavage gives rise to four smaller animal blastomeres and four larger vegetal blastomeres. During subsequent cleavages, the volume of the blastocoel cavity increases with each additional cleavage. The cleavage after the 128-cell stage marks the beginning of blastulation. By the end of blastula- lar body is formed and extruded to lie at the animal pole. A female pronucleus does not form during this process; instead, there are several vesicles containing the maternal chromosomes that migrate to the cortical cytoplasm about $25^{\circ}$ from the animal pole. Here, they join with the sperm nucleus that migrates from the vegetal pole accompanied by a cloud of mitochondria (Holland and Holland, 1992; Holland and Onai, 2012)(Fig. 3A). The gathering of mitochondria near the fusing pronuclei establishes an asymmetry in the fertilized egg and likely influences the position of the DV axis (Holland and Holland, 2007; Holland and Onai, 2012). On the other hand, a recent report showed that sperm can enter the amphioxus egg anywhere, with some preference for the region along the equator (Morov et al., 2016). It also showed that at 5 min after fertilization, the male pronucleus does not show any regional preference (Fig 3B), and the male and female pronuclei meet on one side of the animal hemisphere near the equator approximately 20 min after fertilization (Morov et al., 2016). From
A
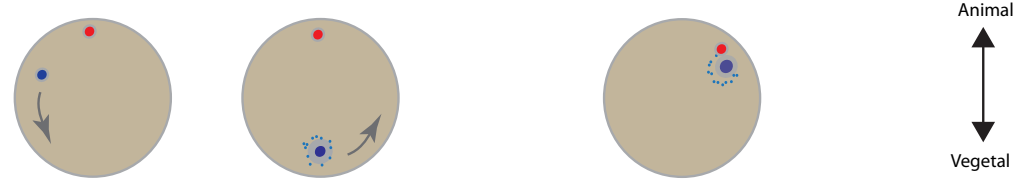

B
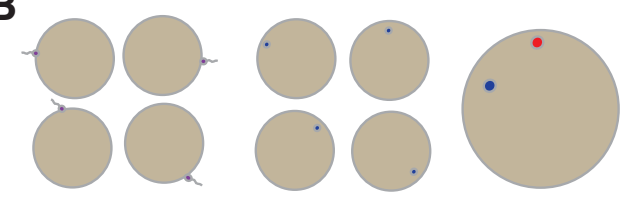

5

10

20
1

(1)
0

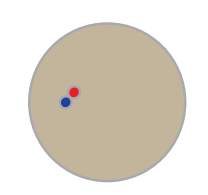

Fig. 3. Schemes illustrating sperm entry points in amphioxus zygotes according to divergent opinions (A,B). The animal pole is at the top. Blue represents the male and red represents the female pronucleus. Light blue dots around mail pronuclei represent mithochondria. Rightward arrow indicates the time of development. Up-down arrow indicates the positions of animal and vegetal poles in the embryos. According to the data from: (Holland and Onai, 2012) and (Morov et al., 2016). 


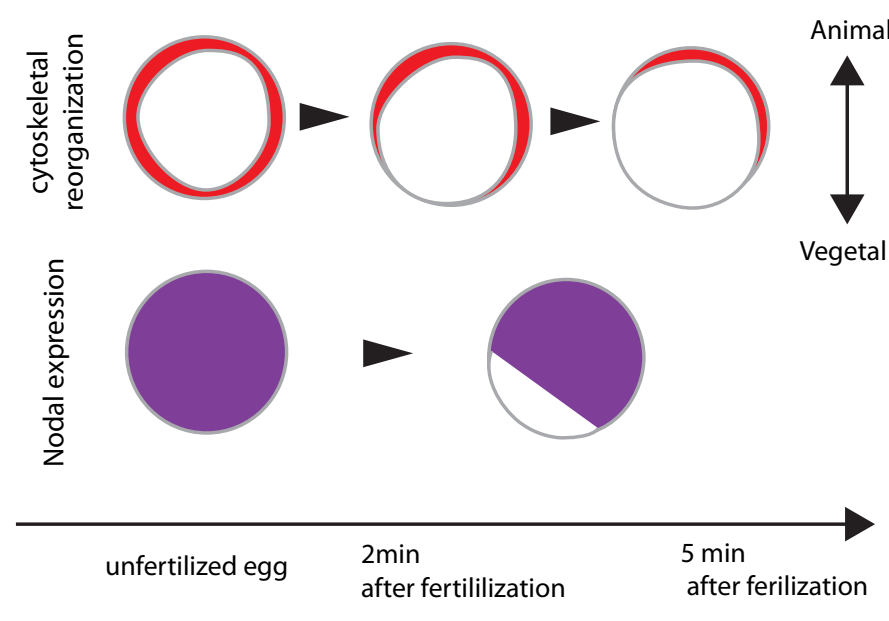

Fig. 4. Cytoskeletal reorganization within the early amphioxus embryo. Red indicates the active Arp2/3 complex, and violet indicates Nodal mRNA. Rightward arrow indicates the time of development. Up-down arrow indicates the positions of animal and vegetal poles in the embryos. According to (Morov et al., 2016).

tion, the difference in the cell size between the vegetal and animal blastomeres is still noticeable, and the second polar body marks the animal pole of the embryo (Hirakow and Kajita, 1990).

During the cleavage stage, the NodalmRNA is asymmetrically distributed and remains largely restricted to the animal two-thirds of the embryo until the 128-cell stage (Fig. 2) (Morov et al., 2016; Onai et al., 2010). Vg1 expression remains ubiquitous (Onai et al., 2010). Interestingly, high levels of amphioxus GDF 8/11, an orthologue of vertebrate GDF8 and GDF11 that signal through Smad2/3 mediators (Egerman et al., 2015), were detected at the one-cell and blastula stages using RT-PCR (Xing et al., 2007). The zygotic expression of Lefty is initiated at the 32-cell stage, and it is restricted to a subset of blastomeres located at one side of the vegetal pole (Fig. 2) (Morov et al., 2016; Onai et al., 2010). This asymmetrical distribution is maintained during blastulation and likely marks the presumptive dorsal cells (Onai et al., 2010).

The components of the canonical Wnt signaling pathway, including Frizzled, Lrp5/6, Axin, Gsk3 $\beta, A P C$, Gro, Ckl $\alpha, C k l 3 \beta$, and $C k l \delta$, remain ubiquitously expressed until the end of blastulation (Qian et al., 2013; Wang et al., 2016b). Similar to the one-cell stage, the transcripts of Dishevelled and Tcf are asymmetrically distributed toward the animal pole during the cleavage and blastula stages (Fig. 2) (Lin et al., 2006; Wang et al., 2016b). It should be noted that current data regarding the nuclear distribution of $\beta$-catenin protein during the cleavage and blastulation of amphioxus are not fully consistent between different species. According to one report that used $B$. floridae, the nuclear localization of $\beta$-catenin starts from the 16-cell stage in all nuclei, and it remains uniformly localized in the whole embryo throughout the blastula stage; however, subsequently, at the onset of gastrulation, nuclear $\beta$-catenin becomes undetectable throughout the vegetal half of the embryo (Fig. 2) (Holland et al., 2005). Another study that used B. belcheri/ japonicum showed that nuclear $\beta$-catenin is initially localized in the nucleus in all blastomeres at the 64-cell stage (Fig. 2), but that a gradient of nuclear $\beta$-catenin protein signal is observed from the early gastrula stage, when a higher concentration is observed on the dorsal side (Yasui et al., 2002). Because these two studies used different antibodies to detect $\beta$-catenin and were performed in different species, further examination using the same antibody across different species is required to resolve this issue.

$B m p 2 / 4$ was reported to be ubiquitously expressed at the 4-cell and 16-cell stages, suggesting the presence of maternal Bmp signals within the amphioxus embryo (Morov et al., 2016). Transcripts for Bmp5/8 and Admp were not detected at the onecell, cleavage or blastula stage using in-situ hybridization (Yu et al., 2007) (Fig. 2). To our knowledge, no study has described the early developmental expression of amphioxus GDF5, which is an orthologue of vertebrate GDF5, GDF6, and GDF7that signal through phosphorylating Smad1/5/8. Immunostaining for phosphorylated Smad1/5/8 protein has been used to detect Bmp signaling activity in amphioxus embryos at the cleavage and blastula stages (Fig.5) (Kozmikova etal., 2013). The nuclear localization of phosphorylated Smad1/5/8 is first detected in both cells at the 2-cell stage. At the 32-cell stage, the signal is present in all nuclei with slight differences in intensity (Figs. 2 and 5). At the 64-cell stage, a noticeable gradient of intensity appears, with a very weak signal in some vegetal blastomeres (Figs. 2 and 5). Interestingly, the signal is likely weak in the dorsal blastomeres, in which the zygotic expression of Lefty is initiated (Fig. 2). The gradient of phosphorylated Smad1/5/8 is maintained throughout the blastula stage (Fig. 2).

Gastrulation starts with the flattening of the vegetal half in amphioxus embryos, and the flattened vegetal region then invaginates to form the presumptive endomesoderm. As the gastrulation proceeds, the embryos become cup-shaped and exhibit deepened archenteron (Hirakow and Kajita, 1991). During amphioxus gastrulation, organizer-related genes, including Chordin, Tsg, and Goosecoid, are co-expressed with Nodal, Lefty, and Admp at the dorsal side of the amphioxus embryo (Morov et al., 2016; Yu et al., 2007). The ventrolateral region is characterized by the expression of Vent1 and Evx genes (Yu et al., 2007). Bmp5/8 and Bmp2/4 are expressed throughout the flattened vegetal plate (Fig. 2) (Morov et al., 2016; Yu et al., 2007), while the activity of Bmp signaling (visualized by phosphorylated Smad1/5 staining) is weaker in the presumptive dorsal part of the embryo compared to that in the ventrolateral region (Figs. 2 and 5), likely due to the presence of Bmp antagonist Chordin in the dorsal side. The amphioxus Vent1 gene has been shown to be a direct target of Smad1/5/8-mediated signaling and is expressed on the opposite side of Chordin (Kozmikova et al., 2011; Yu et al., 2007). Thus, the expression of Vent genes might represent the domain in which Bmp signaling is active within the amphioxus embryo. On the other hand, Lefty, Goosecoid, and Chordin are positively regulated by Smad2/3-mediated signaling (Morov et al., 2016; Onai et al., 2010). Their expression might therefore represent the site at which Nodal signaling is active. Thus, two complementary regions that exhibit opposite gradients of activity of Nodal (Smad2/3-mediated) signaling and Bmp (Smad1/5/8-mediated) signaling are formed in the early gastrula of amphioxus (Kozmikova et al., 2013; Morov et al., 2016; Onai et al., 2010; Yu et al., 2007).

It should be noted that prior to gastrulation in Xenopusembryos, a blastula Chordin- and Noggin-expressing (BCNE) center can be recognized in dorsal animal cells of the marginal region (Kuroda et al., 2004). This BCNE center is involved in the formation of anterior neural tube, and the explanted dorsal BCNE can differentiate into CNS cell types without the signaling input from mesoderm, suggesting that the dorsal animal cap cells are already specified to 
form CNS at the blastula stage in Xenopus. It is currently unclear whether amphioxus blastula has a region that may correspond to the Xenopus BCNE center, because the earliest detectable Chordin expression in amphioxus starts at early gastrula stage during amphioxus development (Morov et al., 2016; Yu et al., 2007) and Noggin gene expression has not been examined yet. Although at the onset of gastrulation amphioxus Chordin is indeed expressed in both dorsal mesoderm and ectoderm, this ectodermal Chordinexpressing region most likely contributes to the future posterior and trunk CNS due to the lack of extensive involution of tissues around the blastopore during amphioxus gastrulation (Zhang et al., 1997), which is in contrast to the Xenopus BCNE center that would eventually involute and contribute to most of the anterior CNS (Kuroda et al., 2004). In addition, a recent study showed that animal cap explants from early gastrula (G1) stage amphioxus embryos were not able to differentiate into CNS tissues autonomously (Le Petillon et al., 2017), suggesting that neural induction probably begins during gastrulation in the amphioxus embryos.

\section{Nodal/Ng1/Activin signaling plays a key role in the for- mation of the amphioxus organizer and neural induction}

Nodal signaling has been shown to play a major role in the DV axis determination in the amphioxus embryo (Le Petillon et al., 2017; Morov et al., 2016; Onai et al., 2010). At the start of gastrulation, both Nodal and Lefty are expressed in the dorsal region (Fig. 2) (Morov et al., 2016; Yu et al., 2007). Similar to what has been observed in vertebrates (Juan and Hamada, 2001; Meno et al., 1999), Smad2/3-mediated signaling positively regulates the expression of amphioxus Lefty at early gastrula and mid-gastrula stages, although additional inputs appear to be required to initiate Lefty's zygotic expression (Le Petillon et al., 2017; Morov et al., 2016). In vertebrates, Leftyitself negatively regulates the Smad2/3mediated signaling and the expression of Nodal (Bisgrove et al., 1999; Branford and Yost, 2002; Feldman et al., 2002). A recent study that used gene-specific knock-out experiments in amphioxus showed that Smad2/3-mediated signaling activates Nodaland Lefty, and that Lefty strongly represses Nodal expression during the late gastrula/neurula stage (Li et al., 2017), suggesting that this autoregulatory loop also occurs during the blastula/early gastrula stages in amphioxus embryos. These Nodal-Lefty regulatory interactions may represent a reaction-diffusion system that operates during the axis establishment in deuterostomes (Branford and Yost, 2002; Duboc et al., 2008). Upregulation of Nodal, Vg1, Lefty, and Smad2/3 at the early neurula stage has also been recently demonstrated when the embryos were treated with human recombinant Activin at the cleavage stage (Le Petillon et al., 2017). Amphioxus Vg1, which is expressed at the blastula and mid-gastrula stages (Fig. 2) (Onai et al., 2010), is likely involved in the regulation of Lefty and establishment of the gradient of Smad2/3-mediated signaling during the blastula and gastrula stages. It was previously shown that treating amphioxus embryos at the early blastula stage with a pharmacological inhibitor of the Smad2/3-mediated pathway led to the elimination of the expression of dorsally specific genes Chordin and $A d m p$, and marker of the presumptive neural plate Sox1/2/3 (Holland et al., 2000b; Kozmikova et al., 2013; Yu et al., 2007) at the mid-gastrula stage (Onai et al., 2010). Similarly, treatment with the same inhibitor at the 64-cell stage resulted in the disappearance of Chordin and Goosecoid expression, the absence of notochord, and the lack of neural plate formation in the neurula stage embryos (Morov et al., 2016). The pharmacological inhibition of Smad2/3-mediated signaling at the early blastula stage also resulted in the upregulation and radialization of posterior ventral marker Evx at the mid-gastrula stage and strong upregulation of the Bmp targets Vent1 and Vent2 genes at the late gastrula stage (Kozmikova et al., 2013). Conversely, ectopic activation of Smad2/3-mediated signaling with human recombinant Activin at the early blastula stage led to the elimination of Exv expression at the mid-gastrula stage (Onai et al., 2010). It was also demonstrated that early ectopic activation of the Smad2/3-mediated pathway at the cleavage stage through the treatment with human recombinant Activin neuralizes the ectoderm of amphioxus embryos at the mid-gastrula and early neurula stages (Le Petillon et al., 2017). Moreover, this neuralization occurs independently of FGF and Bmp signaling pathways, suggesting that the Nodal/Vg1 pathway is a key neural inducer in the organizer of amphioxus (Le Petillon et al., 2017). Together, these data confirm the major role of Nodal/ Vg1 Smad2/3-mediated signaling in the establishment of a proper DV axis in the amphioxus.

\section{Anti-dorsalizing role of Bmp signaling pathway}

Several studies have suggested that Bmp signaling negatively regulates the expression of organizer-specific genes in amphioxus embryos (Kozmikova et al., 2013; Kozmikova et al., 2011; Onai et al., 2010; Yu et al., 2007). At the start of neurulation, amphioxus Chordin marks the dorsal axial mesoderm and neural plate, while Sox1/2/3 is a neural plate marker. Ectopic activation of Bmp signaling (by treatment with zebrafish recombinant BMP4 protein or human recombinant BMP2) at the early blastula stage leads to
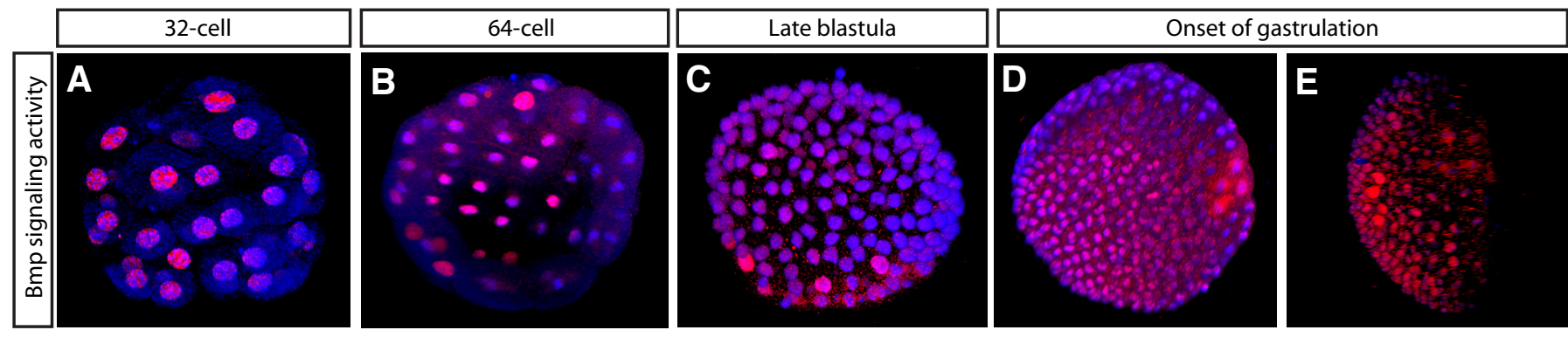

Fig. 5. Staining for phosphorylated Smad1/5/8 shown as 3-D projections of confocal z-stacks. The animal pole is at the top of cleavage and blastula stage embryos (A-C). The embryo at the onset of gastrulation is shown from the vegetal view (D) and lateral view (E) with the presumptive dorsal side at the top. 
the elimination of Chordin and Sox 1/2/3 expression in amphioxus embryos, and the expression of Brachyury, which is a mesodermal marker, is restricted to the circum-blastoporal mesendoderm structures (Kozmikova et al., 2013; Yu et al., 2007); when these embryos reach the larval stage, they are shortened and lack the dorsal structures (Kozmikova et al., 2013; Yu et al., 2007). On the other hand, ectopic activation of Bmp signaling results in the dorsal expansion of the Hex domain, which is normally restricted to the ventral endoderm (Kozmikova et al., 2013; Yu et al., 2007). Similar results showing the downregulation of Chordin, Sox/1/2/3, and Brachyury, expression and the dorsal expansion of the Hex expression domain were obtained by injecting Bmp2/4 mRNA into amphioxus embryos (Onai et al., 2010). Together, these results strongly suggest that Bmp signaling represses the expression of dorsal organizer-specific genes in amphioxus embryos. Similarly as in vertebrates, Bmp signaling acts as an anti-dorsalizing factor during the establishment of the DV axis. This conclusion is further supported by experiments in which Dorsomorphin, a pharmacological inhibitor, was used to block the Bmp signaling during the amphioxus development (Kozmikova et al., 2013). Treatment with Dorsomorphin at the early blastula stage resulted in the upregulation of dorsal marker genes, such as Chordin and Goosecoid, at late gastrula and Sox1/2/3, SoxB1c, and Brn1/2/4 during the early neurula stage, while ventral markers, such as $E v x$ and $T b x 2 / 3$, Vent1, and Vent2, were downregulated during the late gastrula stage (Kozmikova et al., 2013). It should be noted that neither the total expansion of dorsal genes nor the total disappearance of ventral genes was observed in amphioxus embryos that were treated with Dorsomorphin at the early blastula stage (Kozmikova et al., 2013). This may be due to the fact that the Bmp signaling pathway is already operating during the cleavage stages, and thus the expression of its target genes is already initiated before the early blastula stage and then may in turn suppress the dorsal specific genes. Indeed, it has been recently shown that amphioxus embryos that were treated with Dorsomorphin at the cleavage stage displayed a completely dorsalized mesendoderm at the early neurula stage (Le Petillon et al., 2017). However, this inhibition of Bmp signaling did not lead to neuralization of the ectoderm, but instead it blocked ectodermal cell fate commitment (Le Petillon et al., 2017). Le Petillon et al., hypothesized that modest lateral expansion of Brn1/2/4 and Sox1/2/3 at the early neurula stage, observed in a previous study (Kozmikova et al., 2013) for embryos treated with Dorsomorphin at the early blastula stage, reflects the conversion of the neural plate border territory into axial neural ectoderm. Taken together, current data suggest that Bmp signaling is primarily required for the correct DV patterning of mesendoderm in the early amphioxus embryo.

\section{The role of Wnt/ $\beta$-catenin signaling in dorsoventral axis specification and organizer gene expression is still unresolved in amphioxus embryos}

In vertebrates, Wnt/ $\beta$-catenin signaling plays dual roles in DV axis specification by promoting the formation of the dorsal organizer during the cleavage to the blastula stage and then patterning the ventral domain during gastrulation (Hikasa and Sokol, 2013). In the frog and zebrafish, nuclear $\beta$-catenin asymmetrically accumulates in the dorsal cells of the embryo soon after fertilization (Larabell et al., 1997; Rowning et al., 1997; Schneider et al., 1996). However, studies using different amphioxus species have produced inconsistent results regarding the distribution pattern of the $\beta$-catenin protein. One study that used $B$. belcheri/japonicum showed that nuclear $\beta$-catenin signals were asymmetrically distributed from the late cleavage to early gastrula stages (Fig. 2)(Yasui et al., 2002), and the authors suggested that the region with a higher concentration of $\beta$-catenin is the dorsal side (Yasui et al., 2002). Another study that used $B$. floridae showed that nuclear $\beta$-catenin was localized in the cells of the animal half at the onset of gastrulation and then throughout the ectoderm at the mid-gastrula stage (Fig. 2) (Holland et al., 2005). Thus, it remains unclear whether nuclear $\beta$-catenin accumulates asymmetrically in amphioxus embryos during the blastula and early gastrula stages. As for the Wnt ligand genes, Wnt11 is expressed on the presumptive dorsal side during the initial gastrulation and the cup-shaped gastrula stage (Schubert et al., 2000a)(Fig. 2). Interestingly, Dishevelled is also expressed asymmetrically on the presumptive dorsal side at the mid-gastrula stage (Wang et al., 2016a). Wnt1, Wnt3, Wnt5, and Wnt6 were detected around the blastopore from the mid-gastrula stage (Holland et al., 2000a; Schubert et al., 2001). The expression of amphioxus Wnt8 is localized in the area of the blastopore ring from the late blastula stage (Morov et al., 2016) and is expressed dorsolaterally in the cup-shaped gastrula (Schubert et al., 2000b). To our knowledge, the existing functional studies that have evaluated the role of Wnt signaling in early DV patterning in amphioxus have only used treatment involving inhibitors of Gsk3 $\beta$, lithium chloride $(\mathrm{LiCl})$ and Alsterpaulone, which upregulates Wnt/ $\beta$-catenin signaling (Clement-Lacroix et al., 2005). The effects of this treatment on amphioxus embryos depend on the concentration of $\mathrm{LiCl}$ (Holland et al., 2005; Yasui et al., 2002). Holland et al., (2005) showed that when amphioxus embryos ( $B$. floridae) were treated with a high concentrations at the early blastula stage, gastrulation did not proceed normally (Holland et al., 2005), while embryos treated with a lower concentration developed into shortened larvae with a bent tail and a disorganized notochord (Holland et al., 2005). They also showed that treatment with $\mathrm{LiCl}$ had no detectable effect on DV axis patterning when it was applied during the blastula stage, and therefore suggested that the role of $\beta$-catenin in the specification of dorsal identity may be a vertebrate innovation. Nevertheless, the upregulation of $\mathrm{Wnt} / \beta$-catenin signaling by $\mathrm{LiCl}$ at the late blastula stage did not cause the posteriorization of the amphioxus embryos but caused defects in the neural plate (Holland et al., 2005). Additionally, the posterior and ventrolateral expression domains of the $C d x, W n t 3, W n t 1$, and Hex genes were expanded at the late gastrula stage in the amphioxus embryos treated with $\mathrm{LiCl}$ or Alsterpaulone at the early gastrula stage (Onai et al., 2009), and Lim 1/5, which is expressed in the dorsal ectoderm and mesoderm during the late gastrula stage, was significantly downregulated in these embryos (Onai et al., 2009), suggesting that Wnt/ $\beta$-catenin signaling may be involved in the establishment of the ventral/ posterior polarity during amphioxus gastrulation. On the other hand, Yasui et al., reported evidence showing that treating amphioxus embryos ( $B$. belcheri/japonicum) with $\mathrm{LiCl}$ from the 1-cell to the 128-cell stage shifted the Goosecoid and Lhx3 expression domains from the flattening vegetal half to the animal half of the embryo during the initial gastrula stage, and the Otx expression domain was shifted from the future anterior-dorsal region to the ventral side by the same treatment (Yasui et al., 2002). However, at the early neurula stage, the left/dorsal expression of Pitx and 
the expression domains of $\operatorname{Hnf}-3$ (FoxA) in the dorsal and ventral parts of the embryo were unaffected by this treatment (Yasui et al., 2002). Based on these results, Yasui et al., hypothesized that although $\mathrm{LiCl}$ treatment caused the radial expression of dorsal specific genes during the early gastrula stage in the amphioxus, the DV polarity may already have been established by an earlier developmental event (Yasui et al., 2002), possibly by cytoplasmic movements after fertilization (Morov et al., 2016). In our opinion, the data presented in these studies are not sufficient to clearly describe the role of $\mathrm{Wnt} / \beta$-catenin signaling in the formation of the dorsal signaling center in amphioxus; more data, including those from loss-of-function and gain-of-function experiments, are required to resolve this issue.

\section{Conclusions: open questions and future directions}

Previous studies suggest that Nodal and Bmp signaling play major roles in the establishment of the dorsal organizer and patterning of the DV axis during the early development in the amphioxus (Kozmikova et al., 2013; Kozmikova et al., 2011; Le Petillon et al., 2017; Morov et al., 2016; Onai et al., 2010; Yu et al., 2007). However, many issues are not well understood and will require further investigations. The interactions between Nodal, Vg1, and Lefty appear to shape the activity of Smad2/3-mediated signaling, but it remains unclear where exactly this signaling is active during amphioxus development between the cleavage and early gastrula stages. Lefty is one of the earliest zygotically expressed genes in amphioxus; it starts to be expressed at the 32-cell stage in the presumptive dorsal side of the vegetal hemisphere. The initial Lefty expression pattern is distinct from that of Nodal, and co-expression between Nodal and Lefty begins at the blastula stage and is maintained during the early gastrula and mid-gastrula stages (Fig. 2) (Morov et al., 2016). If amphioxus Lefty is positively regulated by Smad2/3 signaling, as reported in other organisms, one can hypothesize that there might be a maternal input of Smad2/3 signaling on the presumptive dorsal side of early amphioxus embryos. Furthermore, it is still unclear whether the zygotic expression of Nodal on the dorsal side of the amphioxus embryo is maintained by Nodal itself or by other inputs. It is also unknown whether Nodal-induced Smad2/3 signaling is the only factor that is necessary and sufficient to initiate the expression of amphioxus dorsal organizer genes. It should be noted that because the expression patterns of the genes that encode these signaling proteins do not necessarily represent the spatiotemporal pattern of their signaling activities, reliable reagents, such as antibodies that can recognize the phosphorylated form of the amphioxus Smad2/3 protein, will be required to convincingly monitor Smad2/3-mediated signaling activities in the amphioxus embryos.

We currently have a better understanding of the signaling activity of Smad 1/5/8-mediated BMP signaling during amphioxus early development (from the 2 -cell stage to the mid-gastrula stage), because the antibodies that can detect the amphioxus Smad1/5/8 protein are available (Kozmikova et al., 2013; Le Petillon et al., 2017; Lu et al., 2012; Morov et al., 2016). However, the expression patterns of some amphioxus ligands (e.g., Bmp5/8 and GDF5/6) during the blastula stage have not yet been investigated, and it is therefore not clear whether these signaling ligands also contribute to the Bmp signaling activity gradient. A recent study demonstrated that Bmp signaling inhibits the expression of Nodal, $\mathrm{Vg}$ 1, and Smad2/3 in the mesendoderm of early amphioxus embryos (Le Petillon et al., 2017). The fact that Bmp signaling represses dorsal organizer specific genes, which are the targets of Smad2/3-mediated signaling, during the blastula and early gastrula stages (Kozmikova et al., 2013; Le Petillon et al., 2017; Onai et al., 2010; Yu et al., 2007) may represent circumstantial evidence that Bmp signaling influences Nodal signaling in the animal portion of the amphioxus embryo during the blastula stage. However, we cannot exclude the possibility that Bmp signaling also directly affects the expression of other organizer genes through the activation of transcription factors, similarly as, e.g., in the case of amphioxus Vent1 and Vent2 genes. Vent1 and Vent2 genes are transcriptional targets of Bmp signaling, and these two transcription factors can directly downregulate the promoters of Chordin and Goosecoid in-vitro (Kozmikova et al., 2011) and repress the expression of amphioxus Chordin in-vivo (Kozmikova et al., 2013; Kozmikova et al., 2011).

As for the role of $\mathrm{Wnt} / \beta$-catenin signaling in early amphioxus embryogenesis, previous studies that have examined the $\mathrm{Wnt} / \beta$ catenin signaling activity using immunostaining have produced divergent results regarding the nuclear distribution of $\beta$-catenin during the blastula and early gastrula stages. In addition, previous functional studies have only used treatment with $\mathrm{LiCl}$ and generated somewhat inconsistent results (Holland et al., 2005; Yasui et al., 2002). To resolve these issues, it is necessary to perform parallel $\beta$-catenin staining using the same antibody in different amphioxus species to confirm the generalized pattern of nuclear $\beta$-catenin distribution in cephalochordate embryos. Moreover, functional studies using more specific chemical inhibitors or agonists of the $W n t / \beta$-catenin signaling pathway, or gene-specific gain-of-function/ loss-of-function experiments are needed to re-examine the role of the $W n t / \beta$-catenin signaling pathway in the amphioxus DV patterning.

In addition to determining how the signaling pathways specify the dorsal and ventral signaling territories, it is also important to identify the corresponding downstream target genes and study their complex regulatory roles during the amphioxus early development. Such a study has previously only been performed for the Vent1 homeobox gene. Bmp signaling has been shown to directly regulate the Vent1 gene through Smad1/5/8 signaling and Smad binding sites in the Vent1 promoter (Kozmikova et al., 2011), and in turn, Vent 1 to directly repress the Chordin and Goosecoid genes via the homeodomain binding sites in their promoters (Kozmikova et al., 2013; Kozmikova et al., 2011). With the recent availability of high-quality genome assembly for $B$. lanceolatum (Acemel et al., 2016) and the advances in next-generation sequencing technologies, we anticipate that further implementation of genome-wide approaches in the amphioxus model will allow us to study the gene regulatory networks underlying its body plan development. This kind of genome-wide unbiased approaches that combine differential RNA-seq of control and pharmacologically treated embryos with chromatin immunoprecipitation-sequencing (ChIP-seq) would be highly useful for deciphering the gene regulatory networks involved in the amphioxus early development.

There is growing evidence demonstrating that many key signaling interactions underlying the DV patterning mechanisms (especially those creating the polarized BMP signaling gradient across the DV axis) are highly conserved among bilaterian animals, and yet variations in how these deeply conserved signaling components are deployed can also be observed (Chang et al., 2016; Denes et al., 2007; Kuo and Weisblat, 2011; Lapraz et al., 2015; Lowe 
et al., 2006; Reddien et al., 2007) and reviewed by (Bier and De Robertis, 2015). One of the most noticeable differences is that the chordate lineage appears to invert its DV axis in relation to the BMP signaling polarity compared to all the other protostome and deuterostome invertebrate animals (Arendt and Nubler-Jung, 1994; De Robertis and Sasai, 1996; Lowe et al., 2006; Yu et al., 2007). Although the mechanism by which this DV axis inversion could have been achieved is still unclear, it has been proposed that it might be accompanied with the origin of Spemann's organizer from the dorsal axial mesoderm and the formation of a new oral opening in the ancestral chordates (Kaji et al., 2016; Lacalli, 2008; Satoh, 2016). Because amphioxus occupies a key position in deuterostome phylogeny, the knowledge generated from comparisons among amphioxus, vertebrates, and non-chordate invertebrates will provide important insights that increase our understanding of the evolutionary origin of the chordate body plan.

\section{Acknowledgements}

The work of IK was supported by the grant 15-21285J from the Czech Science Foundation. The work of JKY is funded by the Academia Sinica and by grants 104-2923-B-001-002-MY3 and 105-2628-B-001-003-MY3 from the Ministry of Science and Technology (MOST), Taiwan. We wish to thank Sarka Takacova for proofreading the manuscript.

\section{References}

ACEMEL, R.D., TENA, J.J., IRASTORZA-AZCARATE, I., MARLETAZ, F., GOMEZMARIN, C., DE LACALLE-MUSTIENES, E., BERTRAND, S., DIAZ, S.G., ALDEA, D., AURY, J.M. et al., (2016). A single three-dimensional chromatin compartment in amphioxus indicates a stepwise evolution of vertebrate Hox bimodal regulation. Nat Genet 48: 336-341.

ANDERSON, C. and STERN, C.D. (2016). Organizers in Development. Curr Top Dev Biol 117: 435-454.

ARENDT, D. and NUBLER-JUNG, K. (1994). Inversion of dorsoventral axis? Nature 371: 26.

BIER, E. and DE ROBERTIS, E.M. (2015). BMP gradients: A paradigm for morphogenmediated developmental patterning. Science 348: aaa5838.

BISGROVE, B.W., ESSNER, J.J. and YOST, H.J. (1999). Regulation of midline development by antagonism of lefty and nodal signaling. Development 126: 3253-3262.

BOURLAT, S.J., JULIUSDOTTIR, T., LOWE, C.J., FREEMAN, R., ARONOWICZ, J., KIRSCHNER, M., LANDER, E.S., THORNDYKE, M., NAKANO, H., KOHN, A.B. et al., (2006). Deuterostome phylogeny reveals monophyletic chordates and the new phylum Xenoturbellida. Nature 444: 85-88.

BRANFORD, W.W. and YOST, H.J. (2002). Lefty-dependent inhibition of nodal- and Wnt-responsive organizer is essential for normal gene expression gastrulation. Curr. Biol. 12: 2136-2141.

CATTELL, M.V., GARNETT, A.T., KLYMKOWSKY, M.W. and MEDEIROS, D.M. (2012). A maternally established SoxB1/SoxF axis is a conserved feature of chordate germ layer patterning. Evol Dev 14: 104-115.

CHANG, Y.C., PAI, C.Y., CHEN, Y.C., TING, H.C., MARTINEZ, P., TELFORD, M.J., YU, J.K. and SU, Y.H. (2016). Regulatory circuit rewiring and functional divergence of the duplicate admp genes in dorsoventral axial patterning. Dev Biol410: 108-118.

CLEMENT-LACROIX, P., AI, M., MORVAN, F., ROMAN-ROMAN, S., VAYSSIERE, B., BELLEVILLE, C., ESTRERA, K., WARMAN, M.L., BARON, R. and RAWADI, G. (2005). Lrp5-independent activation of Wnt signaling by lithium chloride increases bone formation and bone mass in mice. Proc NatlAcad Sci USA 102: 17406-17411.

DAILEY, S.C., PLANAS, R.F., ESPIER, A.R., GARCIA-FERNÀNDEZ, J. and SOMORJAI, I.M.L. (2016). Asymmetric Distribution of pl10 and bruno2, New Members of a Conserved Core of Early Germline Determinants in Cephalochordates. Front. Ecol. Evol. 3: 156.

DE ROBERTIS, E.M. (2009). Spemann's organizer and the self-regulation of embryonic fields. Mech Dev 126: 925-941.

DE ROBERTIS, E.M. and KURODA, H. (2004). Dorsal-ventral patterning and neural induction in Xenopus embryos. Annu Rev Cell Dev Biol 20: 285-308.

DE ROBERTIS, E.M. and SASAI, Y. (1996). A common plan for dorsoventral patterning in Bilateria. Nature 380: 37-40.

DELSUC, F., BRINKMANN, H., CHOURROUT, D. and PHILIPPE, H. (2006). Tunicates and not cephalochordates are the closest living relatives of vertebrates. Nature 439: 965-968.

DENES, A.S., JEKELY, G., STEINMETZ, P.R., RAIBLE, F., SNYMAN, H., PRUD'HOMME, B., FERRIER, D.E., BALAVOINE, G. and ARENDT, D. (2007). Molecular architecture of annelid nerve cord supports common origin of nervous system centralization in bilateria. Cell 129: 277-288.

DUBOC, V., LAPRAZ, F., BESNARDEAU, L. and LEPAGE, T. (2008). Lefty acts as an essential modulator of Nodal activity during sea urchin oral-aboral axis formation. Dev. Biol. 320: 49-59.

EGERMAN, M.A., CADENA, S.M., GILBERT, J.A., MEYER, A., NELSON, H.N., SWALLEY, S.E., MALLOZZI, C., JACOBI, C., JENNINGS, L.L., CLAY, I. et al., (2015). GDF11 Increases with Age and Inhibits Skeletal Muscle Regeneration. Cell Metab 22: 164-174.

FELDMAN, B., CONCHA, M.L., SAUDE, L., PARSONS, M.J., ADAMS, R.J., WILSON, S.W. and STEMPLE, D.L. (2002). Lefty antagonism of squint is essential for normal gastrulation. Curr. Biol. 12: 2129-2135.

FRICK, J.E. and RUPPERT, E.E. (1997). Primordial germ cells and oocytes of Branchiostoma virginiae (Cephalochordata, Acrania) are flagellated epithelial cells: Relationship between epithelial and primary egg polarity. Zygote 5: 139-151.

HIKASA, H. and SOKOL, S.Y. (2013). Wnt signaling in vertebrate axis specification. Cold Spring Harb Perspect Biol 5: a007955.

HIRAKOW, R. and KAJITA, N. (1990). An Electron-Microscopic Study of the Development of Amphioxus, Branchiostoma-Belcheri-Tsingtauense - Cleavage. J. Morphology 203: 331-344.

HIRAKOW, R. and KAJITA, N. (1991). Electron-Microscopic Study of the Development of Amphioxus, Branchiostoma-Belcheri-Tsingtauense - the Gastrula. J. Morphology 207: 37-52.

HOLLAND, L.Z. and HOLLAND, N.D. (1992). Early Development in the Lancelet (= Amphioxus) Branchiostoma-Floridae from Sperm Entry through Pronuclear Fusion - Presence of Vegetal Pole Plasm and Lack of Conspicuous Ooplasmic Segregation. Biol. Bull. 182: 77-96.

HOLLAND, L.Z. and HOLLAND, N.D. (2007). A revised fate map for amphioxus and the evolution of axial patterning in chordates. Integr Comp Biol 47: 360-372.

HOLLAND, L.Z., HOLLAND, N.N. and SCHUBERT, M. (2000a). Developmental expression of AmphiWnt1, an amphioxus gene in the Wnt1/wingless subfamily. Dev Genes Evol 210: 522-524.

HOLLAND, L.Z. and ONAI, T. (2012). Early development of cephalochordates (amphioxus). Wiley Interdiscip Rev Dev Biol 1: 167-183.

HOLLAND, L.Z., PANFILIO, K.A., CHASTAIN, R., SCHUBERT, M. and HOLLAND, N.D. (2005). Nuclear beta-catenin promotes non-neural ectoderm and posterior cell fates in amphioxus embryos. Dev Dyn 233: 1430-1443.

HOLLAND, L.Z., SCHUBERT, M., HOLLAND, N.D. and NEUMAN, T. (2000b). Evolutionary conservation of the presumptive neural plate markers AmphiSox $1 / 2 / 3$ and AmphiNeurogenin in the invertebrate chordate amphioxus. Dev Biol 226: 18-33.

HOLLAND, N.D. and HOLLAND, L.Z. (1991). The Fine-Structure of the Growth Stage Oocytes of a Lancelet (=Amphioxus), Branchiostoma-Lanceolatum. Invert. Reprod. Dev. 19: 107-122.

JUAN, H. and HAMADA, H. (2001). Roles of nodal-lefty regulatory loops in embryonic patterning of vertebrates. Genes Cells 6: 923-930.

KAJI, T., REIMER, J.D., MOROV, A.R., KURATANI, S. and YASUI, K. (2016). Amphioxus mouth after dorso-ventral inversion. Zoological Lett 2: 2.

KITISIN, K., SAHA, T., BLAKE, T., GOLESTANEH, N., DENG, M., KIM, C., TANG, Y., SHETTY, K., MISHRA, B. and MISHRA, L. (2007). Tgf-Beta signaling in development. SCi STKE 2007: $\mathrm{cm} 1$.

KOZMIKOVA, I., CANDIANI, S., FABIAN, P., GURSKA, D. and KOZMIK, Z. (2013). Essential role of Bmp signaling and its positive feedback loop in the early cell fate evolution of chordates. Dev Biol 382: 538-554.

KOZMIKOVA, I., SMOLIKOVA, J., VLCEK, C. and KOZMIK, Z. (2011). Conservation and diversification of an ancestral chordate gene regulatory network for dorsoventral patterning. PLOS One 6: e14650.

KUO, D.H. and WEISBLAT, D.A. (2011). A new molecular logic for BMP-mediated 
dorsoventral patterning in the leech Helobdella. Curr Biol 21: 1282-1288.

KURODA, H., WESSELY, O. and DE ROBERTIS, E.M. (2004). Neural induction in Xenopus: requirement for ectodermal and endomesodermal signals via Chordin, Noggin, beta-Catenin, and Cerberus. PLoS Biol 2: E92.

LACALLI, T.C. (2008). Head organization and the head/trunk relationship in protochordates: problems and prospects. Integr Comp Biol 48: 620-629.

LAPRAZ, F., HAILLOT, E. and LEPAGE, T. (2015). A deuterostome origin of the Spemann organiser suggested by Nodal and ADMPs functions in Echinoderms. Nat Commun 6: 8434.

LARABELL, C.A., TORRES, M., ROWNING, B.A., YOST, C., MILLER, J.R., WU, M., KIMELMAN, D. and MOON, R.T. (1997). Establishment of the dorso-ventral axis in Xenopus embryos is presaged by early asymmetries in beta-catenin that are modulated by the Wnt signaling pathway. J Cell Biol 136: 1123-1136.

LE PETILLON, Y., LUXARDI, G., SCERBO, P., CIBOIS, M., LEON, A., SUBIRANA L., IRIMIA, M., KODJABACHIAN, L., ESCRIVA, H. and BERTRAND, S. (2017). Nodal/Activin Pathway is a Conserved Neural Induction Signal in Chordates. Nat Ecol Evol 1: 1192-1200.

LEMAIRE, P. (2011). Evolutionary crossroads in developmental biology: the tunicates. Development 138: 2143-2152.

LI, G., LIU, X., XING, C., ZHANG, H., SHIMELD, S.M. and WANG, Y. (2017). CerberusNodal-Lefty-Pitx signaling cascade controls left-right asymmetry in amphioxus. Proc Natl Acad Sci USA 114: 3684-3689.

LIN, H.C., HOLLAND, L.Z. and HOLLAND, N.D. (2006). Expression of the AmphiTcf gene in amphioxus: insights into the evolution of the TCF/LEF gene family during vertebrate evolution. Dev Dyn 235: 3396-3403.

LIU, A. and NISWANDER, L.A. (2005). Bone morphogenetic protein signalling and vertebrate nervous system development. Nat Rev Neurosci 6: 945-954.

LOWE, C.J., TERASAKI, M., WU, M., FREEMAN, R.M., JR., RUNFT, L., KWAN, K., HAIGO, S., ARONOWICZ, J., LANDER, E., GRUBER, C. et al., (2006). Dorsoventral patterning in hemichordates: insights into early chordate evolution. PLoS Biol 4: e291.

LU, T.M., LUO, Y.J. and YU, J.K. (2012). BMP and Delta/Notch signaling control the development of amphioxus epidermal sensory neurons: insights into the evolution of the peripheral sensory system. Development 139: 2020-2030.

MACDONALD, B.T. and HE, X. (2012). Frizzled and LRP5/6 receptors for Wnt/betacatenin signaling. Cold Spring Harb Perspect Biol 4: a007880.

MENO, C., GRITSMAN, K., OHISHI, S., OHFUJI, Y., HECKSCHER, E., MOCHIDA, K., SHIMONO, A., KONDOH, H., TALBOT, W.S., ROBERTSON, E.J. et al., (1999). Mouse Lefty2 and zebrafish antivin are feedback inhibitors of nodal signaling during vertebrate gastrulation. Mol Cell 4: 287-298.

MOON, R.T. and KIMELMAN, D. (1998). From cortical rotation to organizer gene expression: toward a molecular explanation of axis specification in Xenopus. Bioessays 20: 536-545.

MOROV, A.R., UKIZINTAMBARA, T., SABIROV, R.M. and YASUI, K. (2016). Acquisition of the dorsal structures in chordate amphioxus. Open Biol 6: 160062.

MULLINS, R.D., HEUSER, J.A. and POLLARD, T.D. (1998). The interaction of Arp2/3 complex with actin: nucleation, high affinity pointed end capping, and formation of branching networks of filaments. Proc Natl Acad Sci USA 95: 6181-6186.

NIEHRS, C. (2004). Regionally specific induction by the Spemann-Mangold organizer. Nat Rev Genet 5: 425-434.

ONAI, T., LIN, H.C., SCHUBERT, M., KOOP, D., OSBORNE, P.W., ALVAREZ, S., ALVAREZ, R., HOLLAND, N.D. and HOLLAND, L.Z. (2009). Retinoic acid and Wnt/ beta-catenin have complementary roles in anterior/posterior patterning embryos of the basal chordate amphioxus. Dev Bio/ 332: 223-233.

ONAI, T., YU, J.K., BLITZ, I.L., CHO, K.W. and HOLLAND, L.Z. (2010). Opposing Nodal/Vg1 and BMP signals mediate axial patterning in embryos of the basal chordate amphioxus. Dev Biol 344: 377-389.

PAPANAYOTOU, C. and COLLIGNON, J. (2014). Activin/Nodal signalling before implantation: setting the stage for embryo patterning. Philos Trans $R$ Soc Lond B Biol Sci 369: 20130539

POLLARD, T.D. (2007). Regulation of actin filament assembly by Arp2/3 complex and formins. Annu Rev Biophys Biomol Struct 36: 451-477.

QIAN, G., LI, G., CHEN, X. and WANG, Y. (2013). Characterization and embryonic expression of four amphioxus Frizzled genes with important functions during early embryogenesis. Gene Expr Patterns 13: 445-453.
RANGE, R. (2014). Specification and positioning of the anterior neuroectoderm in deuterostome embryos. Genesis 52: 222-234.

REDDIEN, P.W., BERMANGE, A.L., KICZA, A.M. and SANCHEZ ALVARADO, A (2007). BMP signaling regulates the dorsal planarian midline and is needed for asymmetric regeneration. Development 134: 4043-4051.

ROWNING, B.A., WELLS, J., WU, M., GERHART, J.C., MOON, R.T. and LARABELL, C.A. (1997). Microtubule-mediated transport of organelles and localization of beta-catenin to the future dorsal side of Xenopus eggs. Proc Natl Acad Sci U S A 94: 1224-1229.

SARDET, C., PAIX, A., PRODON, F., DRU, P. and CHENEVERT, J. (2007). From oocyte to 16-cell stage: Cytoplasmic and cortical reorganizations that pattern the ascidian embryo. Developmental Dynamics 236: 1716-1731.

SATOH, N. (2016). Chordate origins and evolution: the molecular evolutionary road to vertebrates. Academic Press, London, UK.

SCHNEIDER, S., STEINBEISSER, H., WARGA, R.M. and HAUSEN, P. (1996). Beta-catenin translocation into nuclei demarcates the dorsalizing centers in frog and fish embryos. Mech Dev 57: 191-198.

SCHUBERT, M., HOLLAND, L.Z. and HOLLAND, N.D. (2000a). Characterization of an amphioxus wnt gene, AmphiWnt11, with possible roles in myogenesis and tail outgrowth. Genesis 27: 1-5.

SCHUBERT, M., HOLLAND, L.Z., PANOPOULOU, G.D., LEHRACH, H. and HOLLAND, N.D. (2000b). Characterization of amphioxus AmphiWnt8: insights into the evolution of patterning of the embryonic dorsoventral axis. Evol Dev 2: 85-92.

SCHUBERT, M., HOLLAND, L.Z., STOKES, M.D. and HOLLAND, N.D. (2001). Three amphioxus Wnt genes (AmphiWnt3, AmphiWnt5, and AmphiWnt6) associated with the tail bud: the evolution of somitogenesis in chordates. Dev Biol 240: 262-273.

SPEMANN, H. and MANGOLD, H. (1924). Über Induktion von Embryonalanlagen durch Implantation artfremder Organisatoren. Archiv fürMikroskopischeAnatomie und Entwicklungsmechanik 100: 599-638. (translated, re-edited and reprinted in Int J Dev Biol 45: 15-38.

STAMOS, J.L. and WEIS, W.I. (2013). The beta-catenin destruction complex. Cold Spring Harb Perspect Biol 5: a007898.

THISSE, B. and THISSE, C. (2015). Formation of the vertebrate embryo: Moving beyond the Spemann organizer. Semin Cell Dev Biol 42: 94-102.

TUAZON, F.B. and MULLINS, M.C. (2015). Temporally coordinated signals progressively pattern the anteroposterior and dorsoventral body axes. Semin Cell Dev Biol 42: 118-133.

TUNG, T.C., WU, S.C. and TUNG, Y.Y.F. (1962). Experimental Studies on Neura Induction in Amphioxus. Scientia Sinica 11: 805-820.

WANG, J., LI, G., QIAN, G.H., HUA, J.H. and WANG, Y.Q. (2016a). Expression analysis of eight amphioxus genes involved in the Wnt/beta-catenin signaling pathway. Dongwuxue Yanjiu 37: 136-143.

WANG, J., LI, G., QIAN, G.H., HUA, J.H. and WANG, Y.Q. (2016b). Expression analysis of eight amphioxus genes involved in the Wnt/beta-catenin signaling pathway. Zool. Res. 37: 136-143.

WU, H.R., CHEN, Y.T., SU, Y.H., LUO, Y.J., HOLLAND, L.Z. and YU, J.K. (2011). Asymmetric localization of germline markers Vasa and Nanos during early development in the amphioxus Branchiostoma floridae. Dev Biol 353: 147-159.

XING, F., TAN, X., ZHANG, P.J., MA, J., ZHANG, Y., XU, P. and XU, Y. (2007). Characterization of amphioxus GDF8/11 gene, an archetype of vertebrate MSTN and GDF11. Dev Genes Evol 217: 549-554.

YASUI, K., LI, G., WANG, Y., SAIGA, H., ZHANG, P. and AIZAWA, S. (2002). betaCatenin in early development of the lanceletembryo indicates specific determination of embryonic polarity. Dev Growth Differ 44: 467-475.

YU, J.K., SATOU, Y., HOLLAND, N.D., SHIN, I.T., KOHARA, Y., SATOH, N., BRONNERFRASER, M. and HOLLAND, L.Z. (2007). Axial patterning in cephalochordates and the evolution of the organizer. Nature 445: 613-617.

YUE, J.X., LI, K.L. and YU, J.K. (2015). Discovery of germline-related genes in Cephalochordate amphioxus: A genome wide survey using genome annotation and transcriptome data. Mar Genomics 24: 147-157.

ZHANG, Q.J., LUO, Y.J., WU, H.R., CHEN, Y.T. and YU, J.K. (2013). Expression of germline markers in three species of amphioxus supports a preformation mechanism of germ cell development in cephalochordates. EvoDevo 4: 17.

ZHANG, S.C., HOLLAND, N.D. and HOLLAND, L.Z. (1997). Topographic changes in nascent and early mesoderm in amphioxus embryos studied by Dil labeling and by in situ hybridization for a Brachyury gene. Dev Genes Evol 206: 532-535. 


\section{Further Related Reading, published previously in the Int. J. Dev. Biol.}

From the American to the European amphioxus: towards experimental Evo-Devo at the origin of chordates

Jordi Garcia-Fernàndez, Senda Jiménez-Delgado, Juan Pascual-Anaya, Ignacio Maeso, Manuel Irimia, Carolina Minguillón, Ėlia BenitoGutiérrez, Josep Gardenyes, Stéphanie Bertrand and Salvatore D’Aniello

Int. J. Dev. Biol. (2009) 53: 1359-1366

https://doi.org/10.1387/ijdb.072436jg

Evolution of CUT class homeobox genes: insights from the genome of the amphioxus, Branchiostoma floridae Naohito Takatori and Hidetoshi Saiga

Int. J. Dev. Biol. (2008) 52: 969-977

https://doi.org/10.1387/ijdb.072541nt

Peter Holland, homeobox genes and the developmental basis of animal diversity

Sebastian M. Shimeld

Int. J. Dev. Biol. (2008) 52: 3-7

https://doi.org/10.1387/ijdb.072394ss

Developmental expression of the High Mobility Group B gene in the amphioxus, Branchiostoma belcheri tsingtauense

Xiangwei Huang, Lifeng Wang and Hongwei Zhang

Int. J. Dev. Biol. (2005) 49: 49-46

http://www.intjdevbiol.com/web/paper/041915xh

Cell morphology in amphioxus nerve cord may reflect the time course of cell differentiation T C Lacalli

Int. J. Dev. Biol. (2000) 44: 903-906

http://www.intjdevbiol.com/web/paper/11206331

Embryonic development of heads, skeletons and amphioxus: Edwin S. Goodrich revisited P W Holland

Int. J. Dev. Biol. (2000) 44: 29-34

http://www.intjdevbiol.com/web/paper/10761843

Amphioxus Hox genes: insights into evolution and development

$\mathrm{J}$ Garcia-Fernàndez and $\mathrm{P}$ W Holland

Int. J. Dev. Biol. (1996) 40: S71-S72

http://www.intjdevbiol.com/web/paper/9087701

5 yr ISI Impact Factor $(2013)=2.879$

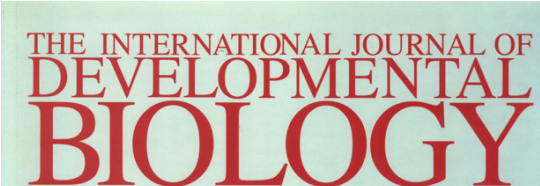

Volume 40 No. 4

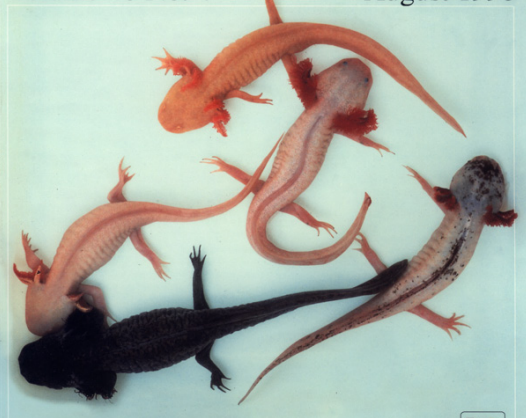

Developmental Biology of Urodeles
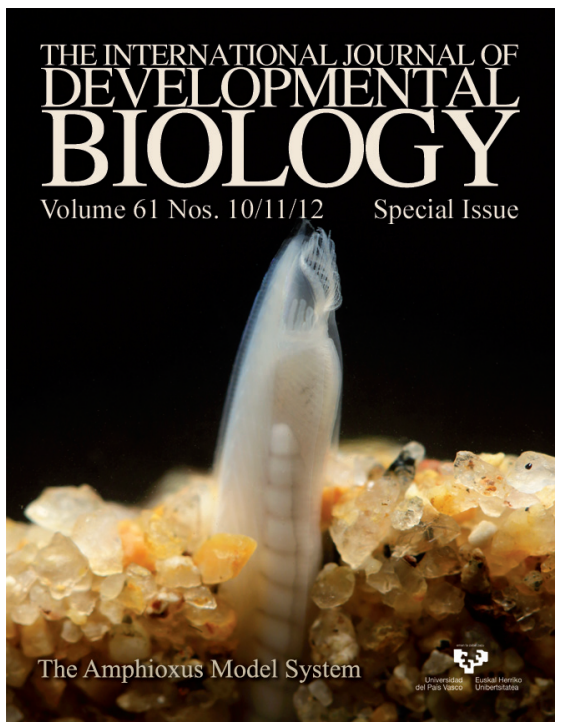

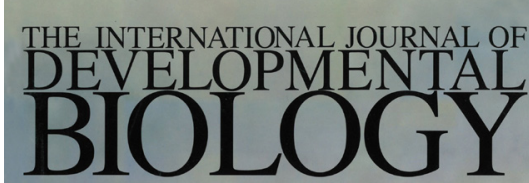

Volume 47 Nos. $7 / 8$ Special Issue

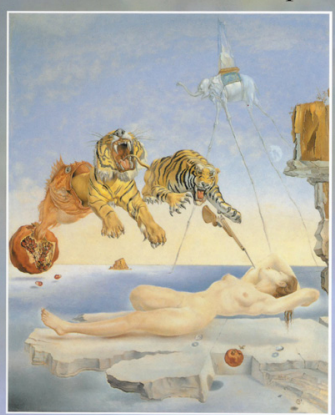

Evolution \& Development

5

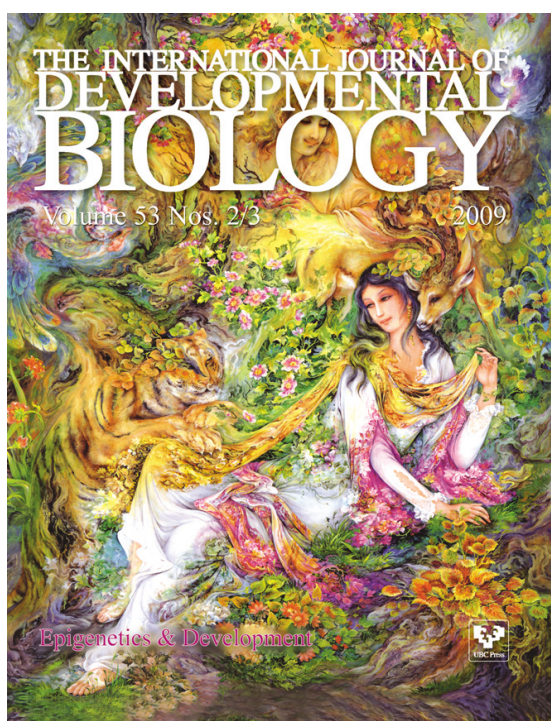

